\title{
Eco $^{2}$ : a simple index of economic-ecological deficits
}

\author{
U. Rashid Sumaila ${ }^{1, *}$, Ngaio Hotte ${ }^{1}$, Alessandro Galli ${ }^{2}$, Vicky W. Y. Lam ${ }^{1}$, \\ Andrés M. Cisneros-Montemayor ${ }^{1}$, Mathis Wackernagel ${ }^{3}$
}

\author{
${ }^{1}$ Fisheries Economics Research Unit, University of British Columbia, 2202 Main Mall, Vancouver, BC V6T 1Z4, Canada \\ ${ }^{2}$ Global Footprint Network, International Environment House 2, 7-9 Chemins de Balexert, 1219 Geneva, Switzerland \\ ${ }^{3}$ Research and Standards Department, 312 Clark Street, 3rd floor, Global Footprint Network, Oakland, CA 94607-3510, USA
}

\begin{abstract}
We present the first joint analysis of the ecological-financial deficits of nations and develop a simple index, the $\mathrm{ECO}^{2}$ index, which is useful in ranking the combined ecological and financial performance of countries. This index includes information on ecological and financial deficits, trade surplus and gross domestic product (GDP) to evaluate the potential impacts of ecological deficits on the overall economic performance of countries. Results show an ongoing trend towards increased ecological deficits, as natural resources are 'traded' for financial gain. We argue that countries cannot run large financial deficits forever without negative economic consequences and that globally, it is likewise impossible to ignore our global ecological deficit in the long run. Ecological deficits can only be temporarily and partially addressed by incurring financial costs through imports, bounded by available resource surpluses of other nations and the fact that some of these services are place-specific. Ultimately, ecological deficits jeopardize ecosystem functions, energy sources and the food security of nations, with direct implications for human well-being.
\end{abstract}

KEY WORDS: Global analysis $\cdot$ Economic $\cdot$ Ecological $\cdot$ Financial $\cdot$ Deficit

\section{INTRODUCTION}

Financial and ecological deficits are usually examined in isolation, leading researchers and decision makers to separately focus on these issues, and on ways to address them; thus, a combined view of the implications of these deficits is currently not common in the literature or at the governance level, where a 'silo mentality' appears to be the norm (Galli 2015). Further, there is growing recognition that ecological deficits and the likely ecosystem degradation associated with them have important implications for financial deficits and vice versa (Stern 2007, TEEB 2010, Bellard et al. 2012, Hill Clarvis et al. 2013). Ecosystem services (e.g. water regulation and food provisioning) have important and direct effects on human well-being (Mace et al. 2014). Adopting a macro-level approach, this paper highlights the relationship be- tween financial and ecological deficits at the national and global scale, and aims at initiating a debate on the global needs for interconnected environmental and financial policies.

Financial deficits are defined and reported by the World Bank (2014) as national government spending in excess of government revenues data. According to Wackernagel et al. (2002), countries run ecological deficits when their demand for renewable resources and ecological services exceeds their ecosystems' capacity to renew such resources and services. Galli et al. (2014) have found that significant biocapacity deficits exist in many countries and that they likely undermine the prosperity of ecosystems and the species that inhabit them. Here, we argue that ecological deficits accumulated by a country are just as concerning as accruing financial deficits due to the fact that all anthropogenic economic activities ultimately 
depend on the biosphere's ecological assets (e.g. Georgescu-Roegen 1971, Daly 1977, Perrings 2005, Costanza et al. 2014a). Yet, trends of financial and ecological deficits are usually compiled and examined in isolation (however, see Tsikliras et al. 2013), leading researchers and decision makers to focus on these issues separately. Here, we developed a simple indicator, the 'ECO' index', which is useful in ranking the combined ecological and financial performance of countries. More than providing definitive numbers, our attempt at developing such a combined index addresses the need to adopt more systemic and crosscutting approaches to deal with sustainability issues.

In this first analysis, $\mathrm{ECO}^{2}$ consists of a simple weighted average of each nation's relative ecological and financial deficits. We then refine the index to $\mathrm{ECO}^{2}$ cost by accounting for the cost of trade in ecological services to offer more detailed information about the potential impacts of ecological deficits on the overall economic performance of countries. Just as a country cannot run huge financial deficits indefinitely, the world as a whole would be unable to function in the long run if we collectively run large yearly ecological deficits, as this would imply a progressive depletion of the world's natural capital (Kitzes et al. 2008, Moore et al. 2012). Recent literature has argued that 4 out of 9 critical planetary thresholds have already been passed (Steffen et al. 2015a) and a critical planetary-scale transition is likely approaching (Barnosky et al. 2012). Profound changes in biosphere integrity could potentially cause irreversible changes and put entire human enterprises at risk (Tittensor et al. 2014, Steffen et al. 2015b).

As many countries, particularly the USA and some members of the EU, wrestle with deepening financial deficits and the resulting ballooning of financial debt, the rapid growth of ecological deficits may often be downgraded to a less pressing priority. Yet, according to Niccolucci et al. (2012), biocapacity - the biosphere's capacity to annually renew resources and ecological services - represents a new type of ecological wealth, which is likely to play a key role in competitiveness and relationships between nations as well as peoples' well-being in the future. As such, ecological deficits present a growing risk to the resilience and sustainability of nations on a global scale (MEA 2005).

While the environmental consequences of surpassing critical environmental thresholds or tipping points continue to be extensively investigated (MEA 2005, Rockström et al. 2009, Pereira et al. 2010, Möllmann et al. 2014, Steffen et al. 2015a), further research is needed to identify the specific relationships between the ecological and financial spheres of nations. Through globalization and trade, a country with an ecological deficit may be able to fill some gaps between the resources it has and the resources it requires as long as it has the financial means to access outside resources. Under such circumstances, a country's capacity to meet its resource requirements becomes limited by the global biocapacity budget (e.g. in low-income countries) and the ability to pay for and import such services (e.g. in highincome countries) (Wackernagel \& Galli 2012). Nevertheless, it must be stressed that regardless of available financial resources, many ecosystem services, such as clean air and water, mitigation of extreme climate events, and access to nature recreation, simply cannot be imported.

Weinzettel et al. (2013) and Lambin \& Meyfroidt (2011), among others, have found that growing consumption patterns in high-income countries are likely amplifying land use changes in low-income nations. Moreover, increasing national and international demand for resources often puts increasing pressure on subsistence land use (Cotula et al. 2009), potentially depriving populations of low-income countries that are relying on subsistence fishing, agriculture and pasturalism, of their ability to support themselves (Rappaport \& Smith 2010). While likely increasing the economic value of production in the short-run, continuation of this development path constitutes a potential long-term threat due to increased ecological deficits (Weinzettel et al. 2013). Eventually, both ecological and financial deficits must be confronted if we are to secure the long-term economic prosperity and social well-being of countries (UNDP 2013).

\section{MATERIALS AND METHODS}

Ecological deficits, also referred to as 'biocapacity deficits', are annually computed and reported by the Global Footprint Network (GFN 2014), within their system of National Footprint Accounts (Borucke et al. 2013). Ecological deficits are tracked in terms of national resource consumption and waste discharge, or 'Ecological Footprint' (EF) in excess of locally available regenerative capacity, or 'biocapacity' (Wackernagel et al. 2002). Gross Domestic Product (GDP) and national financial deficit (i.e. national government spending in excess of government revenues) data are reported by the World Bank (2014) and used in our analysis. 
EF and biocapacity values for all countries for the period 1961-2010 were calculated and reported by the GFN (2014) based on the method described by Borucke et al. (2013) (Supplement at www.int-res.com/ article/suppl/m530p271_supp.pdf). National Footprint Accounts are compiled using international data sets published by the Food and Agriculture Organization (FAO) of the United Nations (UN), the UN Statistics Division Commodity Trade Statistics Database, the International Energy Agency (IEA), and peer-reviewed scientific studies. Comprehensive details on the $\mathrm{Na}$ tional Footprint Accounts framework and calculation methodology are provided by Borucke et al. (2013). EF and biocapacity indicate human demand for, and nature's supply of, life supporting resource provisioning (e.g. food resources, fibers, etc.), regulatory (climate stabilization via $\mathrm{CO}_{2}$ sequestration) and supporting ecosystem services (MEA 2005) associated with 6 types of ecosystems: cropland, grazing land, fishing grounds, forest land, built-up land, and uptake land for carbon assimilation (Galli et al. 2014, Galli 2015). According to Galli (2015, p. 211), 'while nature provides many ecosystem services, the rationale for including these particular services is that they directly compete for Earth's biologically productive surfaces and can thus be measured in terms of the biologically productive area necessary to provide them'.

For each country included in the analysis, the demand for resource provisioning and regulatory ecosystem services was first divided by the yield of services by land type. The values obtained were then multiplied by equivalence factors and summed together to generate final national EF values in terms of hectare-equivalent units (i.e. global hectares of land, gha). Total availability of biocapacity in each country was calculated as the sum of the biocapacity supplied by each land type, i.e. the rate of resource supply and effluent waste disposal that can be sustained by that land type under current technology and management schemes (Monfreda et al. 2004, Borucke et al. 2013). EF values were then compared with local supply of ecosystem services (i.e. biocapacity) to calculate a nation's ecological reserve (footprint $<$ biocapacity) or deficit (footprint > biocapacity) situation. In this study, this deficit was further divided by the country's biocapacity, providing a final ecological deficit expressed as a percentage of available biocapacity.

Financial data for the period 1961-2010 were obtained from the World Bank (2014) for all countries. National deficit (or surplus) to GDP, which represents the difference between governmental receipts and spending, was used to evaluate the financial performance of these countries. In order to account for differ- ences between the sizes of national economies, deficits were expressed as a proportion of GDP. Deficits were examined and compared at the national, continental, and global levels and for high-, middle- and low-income countries, as categorized by World Bank (2014).

Complete ecological (i.e. EF, biocapacity) and financial (i.e. national deficit, GDP) data were available for a total of 149 countries for the year 2010. The ecological and financial deficits of nations were first analyzed independently, and then evaluated jointly using the $\mathrm{Eco}^{2}$ index (Supplement). Country data were examined by continent and income group, as well as globally to examine broad trends in ecological and financial performance.

\section{A national Eco ${ }^{2}$ index}

The basic Eco ${ }^{2}$ index was calculated as the weighted average of the 2 deficits, using the expression:

$$
\mathrm{ECo}^{2}=\frac{\alpha_{1} \mathrm{ED}+\alpha_{2} \mathrm{FD}}{2}
$$

where ED and FD are the respective percentage points of ecological and financial deficits (or surpluses), and $\alpha_{1}$ and $\alpha_{2}$ denote the respective weights assigned to the financial and ecological deficits. As a baseline, we used $\alpha_{1}=\alpha_{2}=1$; we subsequently conducted sensitivity analyses assuming weights of $\alpha_{1}=2 \alpha_{2}$ and $\alpha_{2}=$ $2 \alpha_{1}$. The resulting $\mathrm{ECO}^{2}$ index may be positive, zero, or negative. A negative index value indicates an ecological-financial deficit, while a positive value indicates a surplus. This simple index was constructed to help communicate, in a simple way, the existence and implications of combined ecological and financial deficits in countries. It is worth noting that the construction of such an index was not meant to imply that the 2 deficits are always substitutable or interchangeable.

\section{Including the role of global trade in ecological services: the $\mathrm{Eco}^{2}{ }_{\text {cost }}$ index}

Here, we estimate the combined costs of ecological and financial deficits compared to GDP. $\mathrm{ECO}^{2}{ }_{\text {cost }}$ is a modification of the $\mathrm{Eco}^{2}$ index to account for costs incurred through trade in ecological services, and is expressed as follows:

$$
\mathrm{ECO}_{\text {cost }}^{2}=\frac{\mathrm{FD}+\mathrm{Cost}}{\mathrm{GDP}}
$$

where FD denotes annual financial deficit (or surplus) and Cost represents the annual cost of the eco- 
logical deficit (or surplus), which is the product of the annual ecological deficit and the global average cost per hectare (gha) of the sub-set of ecological services analyzed by the Footprint methodology.

As a first approximation, the cost per gha of ecological services was calculated by applying the average value of ecosystem services provided by Costanza et al. (2014b). Although the method used to derive this estimate in that paper has been criticized (Toman 1998), it remains one of only 2 (the other is provided by de Groot et al. 2012) published global assessment methods to date to assign monetary values to ecological services from various biome types. de Groot et al. (2012) expands on the literature review method developed by Costanza et al. (1997), but does not provide a total global estimate of ecosystem services value. For biomes included in both studies, median monetary values are on average $4 \times$ as high in de Groot et al. (2012).

Here, the Costanza et al. (2014b) estimate served as a first benchmark. A constant cost per gha was calculated by dividing the total ecological services value of US\$125 trillion $\mathrm{yr}^{-1}$ reported by (Costanza et al. 2014 b) by an estimated total global hectares of 52 billion to obtain a per gha value of US\$2416 ${ }^{1}$. The amount was converted to roughly US\$2500² per gha using the Consumer Price Index reported by the International Monetary Fund for both years (see www.imf.org/external/pubs/cat/longres.cfm?sk $=17165.0$ ). To explore how different assumptions on gha values are likely to affect the results of our study, we carried out sensitivity analyses using a cost per gha of US\$1250 and US\$5000.

\section{RESULTS}

Fig. 1 summarizes data on ecological deficits (Fig. 1A), financial deficits (Fig. 1B), and the $\mathrm{ECO}^{2}$ index (Fig. 1C) for 149 countries around the world for 2010 , which is the most recent year for which data is available.

Countries with the highest combined surplus, according to this Eco ${ }^{2}$ index, are Timor-Leste, Gabon, Bolivia, Republic of Congo, and the Central African Republic (Fig. 2A, Supplement), while the ones with the highest deficits are Lebanon, the United Arab Emirates, Israel, Kuwait, and Singapore (Fig. 2B, Supplement). Results suggest that countries that do

\footnotetext{
1This is in constant 2007 dollars

2When the per gha value was converted from 2007 to 2010 constant dollars
}

well are usually natural resource-rich countries that are relatively self-sufficient and export part of their resources, e.g. Gabon. On the other hand, countries with limited natural resources, but high populations and the purchasing power to meet demand through imports, achieve low scores.

On average, countries are running ecological deficits that are proportionately higher than their financial deficits or surpluses, reflecting a general tendency to trade ecological capital for financial capital. Only $30 \%$ (44 out of 149 countries) have a positive $\mathrm{ECO}^{2}$ index; all others have negative indices, indicating that less than one-third of the world is living within its ecological means. Ultimately, both ecological and financial deficits must be avoided over the long term. Large simultaneous (ecological and financial) deficits underscore the extent of the challenges that lie ahead for many countries.

In 2010, Oceania and South America were the only continents with ecological surpluses; South America and Oceania both ran financial deficits; and no continent ran both ecological and financial surpluses (Fig. 2C). Overall, the world ran a small financial surplus in 2010, but showed a large $\mathrm{ECO}^{2}$ deficit (Fig. 2D), implying that the world is 'eating up' its store of ecological capital.

During the nearly 5 decades from 1961 through 2010, the $\mathrm{Eco}^{2}$ index for all countries fell steadily, mainly due to growing ecological deficits in many countries. To calculate $\mathrm{ECO}^{2}$ for this period, we assumed a constant cost per gha. The results for this period reveal that the ecological and financial deficits of low- and middle-income nations (here, 'transition countries') are rising toward those of high-income nations (Fig. 3). During the 1980s, transition countries had positive $\mathrm{Eco}^{2}$ values, but beginning in the 1990s, a strong declining trend carried those values into a combined ecological-financial deficit. This may be due to heightened natural resource-dependent economic activities in transition countries during this period.

Our analysis thus far shows that some countries, e.g. Singapore and Kuwait, have large ecological deficits, but are still able to support high consumption rates. This is possible because they have the financial means to import ecological services through international trade. This consideration led us to the calculation of the $\mathrm{ECO}^{2}$ cost index, which was then used to explore the challenge of ecological deficits from a cost perspective. Some ecological deficits can be compensated for by financial means, but this cost burden imposes economic pressure on the purchasing country, which can compound existing economic stresses and contribute to disruption of the national economy. 

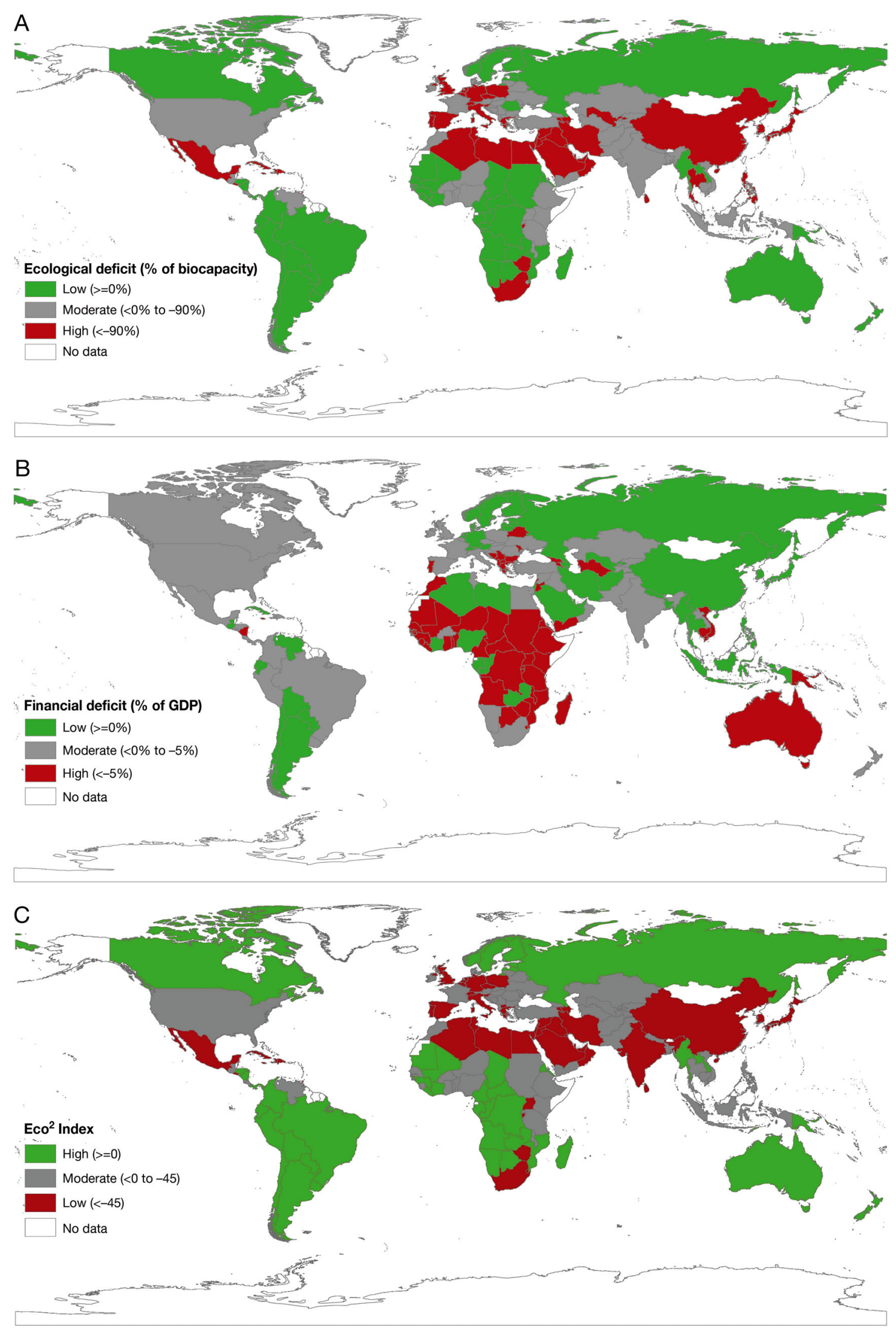

Fig. 1. Global (A) ecological deficits (surpluses), (B) financial deficits (surpluses), and (C) Eco ${ }^{2}$ index values 

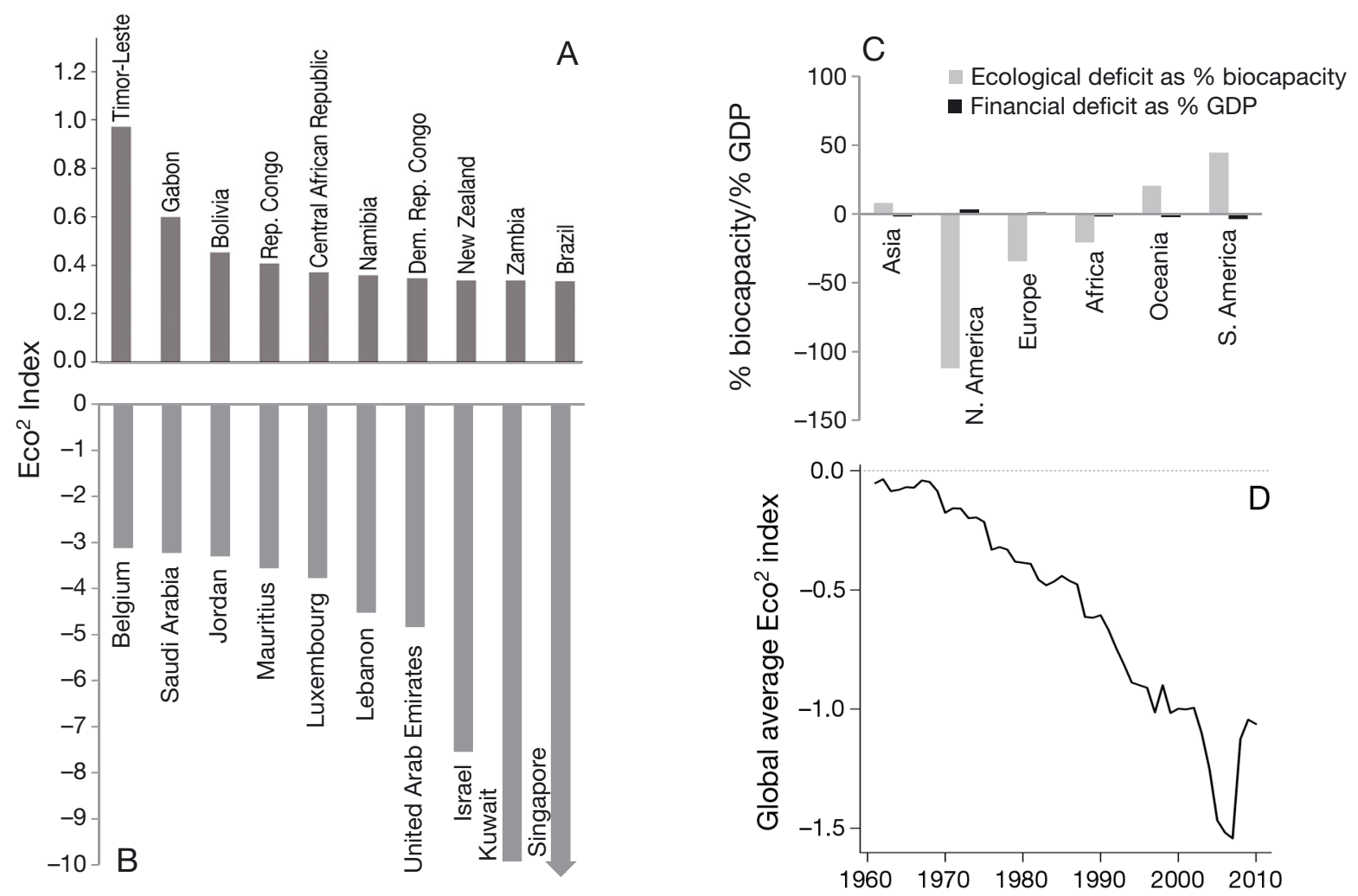

Fig. 2. $\mathrm{Eco}^{2}$ index values based on ecological and financial deficits at the national level. (A) Top 10 countries with the highest $\mathrm{EcO}^{2}$ index values (2010), (B) bottom 10 countries with the lowest Eco ${ }^{2}$ index values (2010), (C) ecological and financial surpluses (or deficits) by continent (2010), and (D) global Eco ${ }^{2}$ index values (1961-2010)

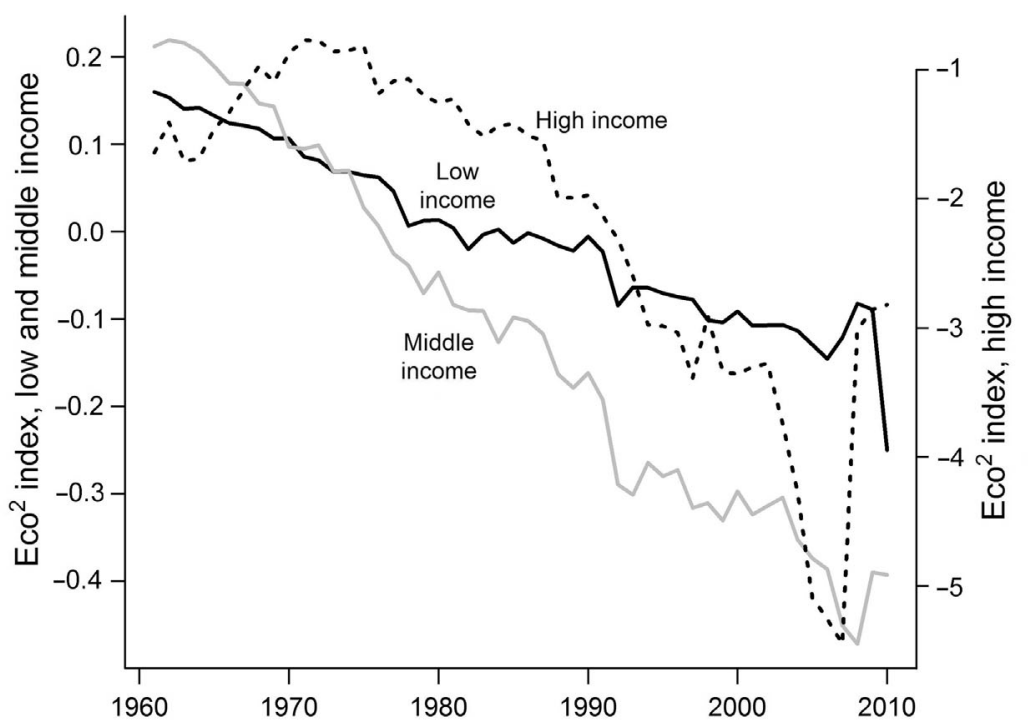

Fig. 3. Average $\mathrm{Eco}^{2}$ index values by income group (1961-2010)

are only beginning to address these issues, we believe that underexploited and/or sustainably used ecological assets will likely represent a new form of wealth in the 21 st century, which will likely play a crucial role in ensuring the long-term economic competitiveness of countries.

Countries with the lowest $\mathrm{Eco}_{\text {cost }}^{2}$ index values are low-income countries, with the exception of Gambia. What is surprising is that this was also true for the countries with the highest $\mathrm{ECO}^{2}{ }_{\text {cost }}$ index scores, with the exception of Gabon and the Republic of Congo, which are middle-income countries. All of the high-income countries fell within the middle of the pack, indicating that GDP may have little to do with national ecological-financial performance; this is a

The results obtained from the $\mathrm{Eco}_{\text {cost }}^{2}$ index calculations are presented in Fig. 4. In the case of topperforming countries, many ran small economic deficits, which are overcompensated for by the amount of their ecological surpluses. While empirical studies result that warrants further analysis in the future.

One key difference in the outcomes of the 2 indices is that countries that have the financial means (e.g. Singapore) improved their index scores under $\mathrm{ECO}^{2}{ }_{\text {cost }}$ at least for now. 


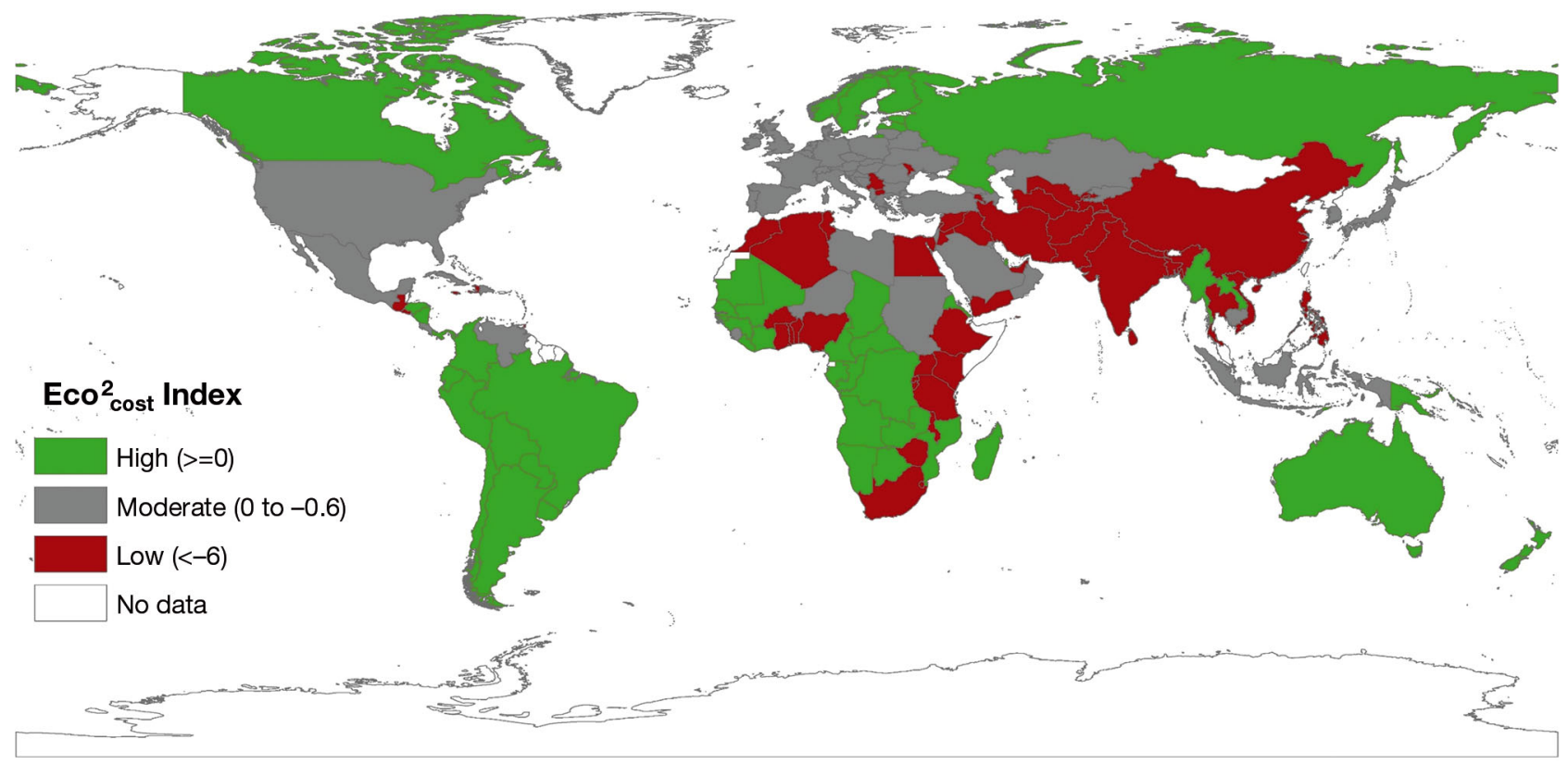

Fig. 4. Global $\mathrm{Eco}^{2}{ }_{\text {cost }}$ index values when ecosystem services are traded and financial and ecological deficit costs are combined

\section{Sensitivity of the $\mathrm{Eco}^{2}$ index to relative weights}

The $\mathrm{Eco}^{2}$ index was calculated as a weighted average of ecological and financial deficits. For the base case analysis, ecological and financial deficits were weighted equally. We also applied weights of 2:1 and 1:2 to our initial calculation to assess how changes in the relative importance assigned to these deficits could affect the results of our analysis. While these varying weights indeed affect the magnitude of results, there is nonetheless a clear decline in ecological deficits at the global level (Fig. 5A).

\section{Sensitivity of the $\mathrm{Eco}^{2}{ }_{\text {cost }}$ index to the cost of ecosystem services}

Here, we re-calculated the $\mathrm{Eco}_{\text {cost }}^{2}$ index using costs of ecosystem services of $\$ 1200$ and $\$ 4800$ per gha. As with the $\mathrm{Eco}^{2}$ index, this sensitivity analysis shows that applying these different cost ratios to all countries does not significantly affect the global trends, or country rankings, of the $\mathrm{Eco}^{2}$ cost index (Fig. 5B).

\section{DISCUSSION AND CONCLUSIONS}

The results of the analysis reveal that ecological and financial deficits are often inversely correlated.
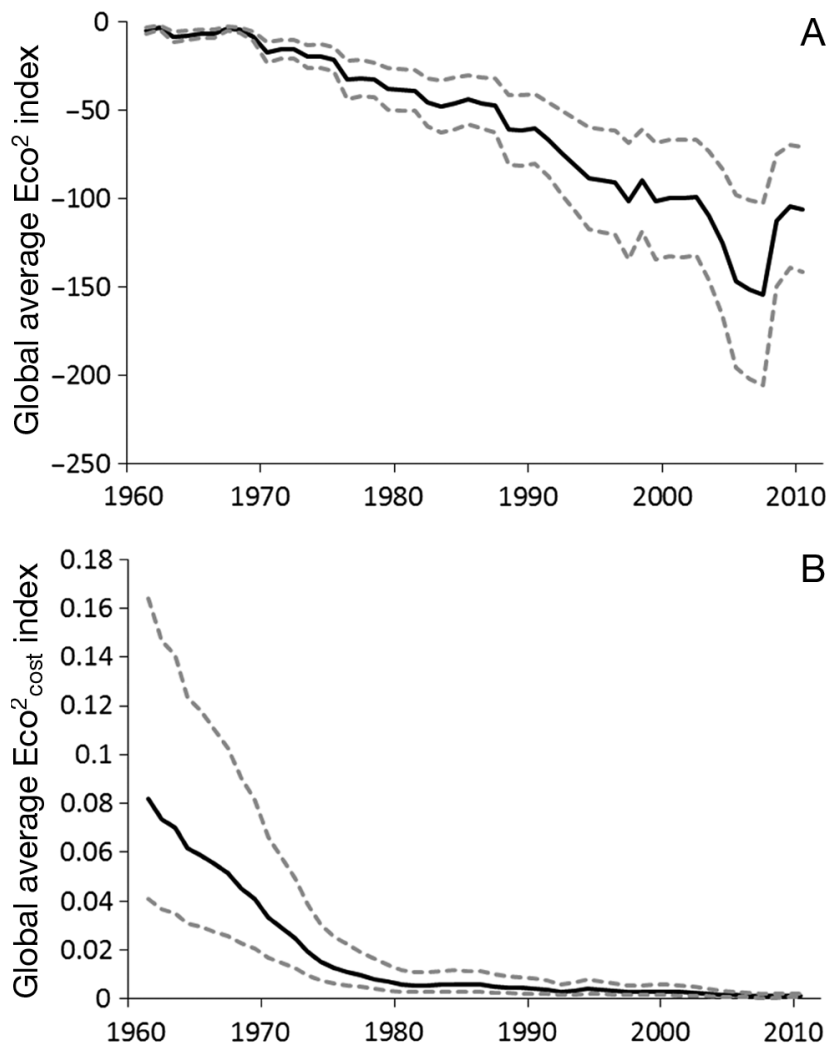

Fig. 5. Sensitivity analysis for data assumptions. (A) Eco ${ }^{2}$ index values (1961-2010) including base scenario $=1: 1(-)$ and ecological:financial weights of 2:1 (top ---) and 1:2 (bottom ---); (B) Eco ${ }^{2}$ cost index values (1961-2010) including base scenario cost $=$ US $\$ 2500$ (一) and costs of $\$ 1250$ (top ---) and $\$ 5000$ (bottom ---) per gha (global hectares of land) 
The $\mathrm{Eco}^{2}$ index shows that high-income countries such as Japan, the United States, several European countries and the Middle East seem to have amassed high ecological deficits concurrently with financial gains. Conversely, the highest combined surpluses are generally recorded in relatively small, natural resource-rich developing countries, such as TimorLeste, Gabon and Bolivia.

Among the debates on current global financial market instability, an item that warrants more emphasis is the ultimate effect of financial debt on the power of nations to acquire goods and services to meet the needs of their populations. While some debt has been historically called for in the interest of economic efficiency, the bottom line is that allowing ecological capital to be degraded undermines the potential capacity for ecosystem service provision if and when it becomes necessary. This occurs, for example, due to the financial inability to import goods when there are insufficient funds or insufficient goods on the market. This includes a host of ecological services, e.g. food provisioning, that can be substituted at a financial cost, but are naturally provided by wellfunctioning ecosystems. The urgency of environmental remediation for human needs (if nothing else) is increasingly recognized, but this work introduces a new discussion by explicitly factoring in financial and ecological capital and debt into future policy development.

Acknowledgements. U.R.S., N.H., V.W.Y.L. and A.M.C.-M. thank the Pew Charitable Trusts for support through the Global Ocean Project. A.G. and M.W. thank MAVA Foundation pour la Nature for support. U.R.S. and A.M.C.-M. also thank the Social Sciences Research Council of Canada (SSHRC) for their support of the Ocean Canada Partnership. Finally, we are grateful to Gemma Cranston, Kyle Gracey and David Moore for their input in developing the ecological deficit concept.

\section{LITERATURE CITED}

Barnosky AD, Hadly EA, Bascompte J, Berlow EL and others (2012) Approaching a state shift in Earth's biosphere. Nature 486:52-58

Bellard C, Bertelsmeier C, Leadly P, Thuiller W, Courchamp $F$ (2012) Impacts of climate change on the future of biodiversity. Ecol Lett 15:365-377

Borucke M, Moore D, Cranston G, Gracey K and others (2013) Accounting for demand and supply of the biosphere's regenerative capacity: the National Footprint Accounts' underlying methodology and framework. Ecol Indic 24:518-533

Costanza R, d'Arge R, de Groot R, Farber S and others (1997) The value of the world's ecosystem services and natural capital. Nature 387:253-260
Costanza R, Kubiszewski I, Giovannini E, Lovins H and others (2014a) Development: time to leave GDP behind. Nature 505:283-285

Costanza R, de Groot R, Sutton P, van der Ploeg S and others (2014b) Changes in the global value of ecosystem services. Glob Environ Change 26:152-158

Cotula L, Vermeulen S, Leonard R, Keeley J (2009) Land grab or development opportunity? Agricultural investment and international land deals in Africa. IIED/FAO/ IFAD, London/Rome

Daly H (1977) Steady-state economics. WH Freeman, San Francisco, CA

de Groot R, Brander L, van der Ploeg S, Costanza R and others (2012) Global estimates of the value of ecosystems and their services in monetary units. Ecosys Serv 1:50-61

Galli A (2015) On the rationale and policy usefulness of Ecological Footprint Accounting: the case of Morocco. Environ Sci Policy 48:210-224

Galli A, Wackernagel M, Iha K, Lazarus E (2014) Ecological footprint: implications for biodiversity. Biol Conserv 173: 121-132

Georgescu-Roegen N (1971) The entropy law and the economic process. Harvard University Press, Cambridge

GFN (Global Footprint Network) (2014) National footprint accounts. Oakland, CA. www.footprintnetwork.org

Hill Clarvis M, Halle M, Mulder I, Yarime M (2013) Towards a new framework to account for environmental risk in sovereign credit risk analysis. J Sustain Fin Invest 4: $147-160$

Kitzes J, Wackernagel M, Loh J, Peller A and others (2008) Shrink and share: humanity's present and future ecological footprint. Philos Trans R Soc Lond B Biol Sci 363:467-475

> Lambin EF, Meyfroidt P (2011) Global land use change, economic globalization, and the looming land scarcity. Proc Natl Acad Sci USA 108:3465-3472

Mace GM, Reyers B, Alkemade R, Biggs R and others (2014) Approaches to defining a planetary boundary for biodiversity. Glob Environ Change 28:289-297

MEA (Millennium Ecosystem Assessment) (2005) Ecosystems and human well-being: synthesis report. Millennium Ecosystem Assessment, Washington, DC

MöllmannC, Folke C, Edwards M, Conversi A (2014) Marine regime shifts around the globe: theory, drivers and impacts. Philos Trans R Soc B 370:20130260

> Monfreda C, Wackernagel M, Deumling D (2004) Establishing national natural capital accounts based on detailed ecological footprint and biological capacity assessments. Land Use Policy 21:231-246

- Moore D, Galli A, Cranston GR, Reed A (2012) Projecting future human demand on the Earth's regenerative capacity. Ecol Indic 16:3-10

Niccolucci V, Tiezzi E, Pulselli FM, Capineri C (2012) Biocapacity vs ecological footprint of world regions: a geopolitical interpretation. Ecol Indic 16:23-30

Pereira HM, Leadley PW, Proença V, Alkemade R and others (2010) Scenarios for global biodiversity in the 21st century. Science 330:1496-1501

Perrings C (2005) Economy and environment: a theoretical essay on the interdependence of economic and environmental systems. Cambridge University Press, Cambridge

> Rappaport SM, Smith MT (2010) Environment and disease risks. Science 330:460-461

Rockström J, Steffen W, Noone K, Persson A and others (2009) A safe operating space for humanity. Nature 461: $472-475$ 
Steffen W, Richardson K, Rockström J, Cornell SE and others (2015a) Sustainability. Planetary boundaries: guiding human development on a changing planet. Science 347 (6223):1259855

Steffen W, Broadgate W, Deutsch L, Gaffney O, Ludwig C (2015b) The trajectory of the Anthropocene: the great acceleration. The Anthropocene Rev 2:81-98

Stern N (2007) The economics of climate change. The Stern review. Cambridge University Press, Cambridge

TEEB (The Economics of Ecosystems and Biodiversity) (2010) Mainstreaming the economics of nature: a synthesis of the approach, conclusions and recommendations of TEEB. www.teebweb.org/

Tittensor DP, Walpole M, Hill SLL, Boyce DG and others (2014) A mid-term analysis of progress toward international biodiversity targets. Science 346:241-244

Toman M (1998) Why not to calculate the value of the world's ecosystem services and natural capital. Ecol Econ 25:57-60

Submitted: August 14, 2014; Accepted: March 12, 2015
Tsikliras CA, Sumaila UR, Stergiou KI (2013) Parallels in economic and ecosystem crises. Ethics Sci Environ Polit $13: 23-25$

UNDP (United Nations Development Programme) (2013). Human development report 2013. The rise of the south: human progress in a diverse world. United Nations Development Programme, NY

Wackernagel M, Galli A (2012) Ecological footprint: economic performance and resource constraints. Glob Dialogue 14. www.worlddialogue.org/content.php?id=512

Wackernagel M, Schulz NB, Deumling D, Linares AC and others (2002) Tracking the ecological overshoot of the human economy. Proc Natl Acad Sci USA 99:9266-9271

Weinzettel J, Hertwich EG, Peters GP, Steen-Olsen S, Galli A (2013) Affluence drives the global displacement of land use. Glob Environ Change 23:433-438

World Bank (2014) World Bank list of economies. http://site resources.worldbank.org/DATASTATISTICS/Resources/ CLASS.XLS (accessed on 7 November 2014)

Proofs received from author(s): May 17, 2015 